\author{
A. Abubakirova ${ }^{1^{*}}$, D. Dilbarkhanova ${ }^{2}$ \\ ${ }^{1}$ Egyptian University of Islamic Culture Nur-Mubarak, Kazakhstan, Almaty \\ ${ }^{2}$ Khoja Akhmet Yassawi International Kazakh-Turkish University, Kazakhstan, Shymkent \\ *e-mail: a.abubakirova.work@gmail.com
}

\title{
DISCURSIVE STUDY OF THE PECULIARITIES OF THE LANGUAGE OF RELIGION
}

At present, religion is integrated into almost all spheres of human life, has experienced a period of revival, and is developing in a new direction. Therefore, the discursive study of religious issues, that is, the analysis of issues related to religion in the context of modern discourse, is an important and relevant area of research. Considering that the purpose of this study is to identify and describe the features of the concept of language according to its nature and use in a religious context, which is closely related to the concept of religion, the main areas of research include religious studies and linguistic views, and it is aimed at demonstrating that the differences between the language of religion and language of everyday use directly contribute to its ability to influence the consciousness of believers, fully conveying religious statements. Research results are important because they show the characteristics and ways of conducting discourse analysis and can help in applying these results. The study used a variety of general and individual scientific methods. The features of the language of religion are revealed, conclusions about their meaning and use are analyzed, a general and complete picture of the language of religion is formed. Knowledge of the general characteristics and capabilities of the language of religion helps to find solutions to many religious problems and prevent them.

Key words: language, language of religion, sign, symbol, linguistics, religious philosophy.

\section{А. Әбубәкірова ${ }^{*}$, А. Аимьбарханова ${ }^{2}$}

'Нүр-Мүбарак Египет ислам мәдениеті университеті, Қазақстан, Алматы к. ${ }^{2}$ Қожа Ахмет Яссауи атындағы Халықаралық қазақ-түрік университеті, Қазақстан, Шымкент қ. *e-mail: a.abubakirova.work@gmail.com

\section{Аін тілі ерекшеліктеріне Аискурсивті талдау}

Қазіргі кезеңде дін адамзат өмірінің барлық саласына дерлік кірігіп, қайта жандану кезеңінен өтіп, жаңғырып, жаңаша дамып жатыр. Міне, сондықтан дін мәселелерін дискурсивті тұрғыда зерттей алу, яғни заманауи дискурс аясында дінге қатысты, Аін тудырған мәселелерді талдау маңызды әрі өзекті зерттеу бағыты болып отыр. Бұл ұсынылып отырған зерттеу жұмысының мақсаты Аін ұғымымен тығыз байланысқан, біте қайнасқан тіл ұғымының Аіни мәнмәтінде тіршілігі мен қолданысына сай ерекшеліктерін айқындау әрі сипаттау екенін ескерсек, зерттеудің негізгі бағыттары дінтанулық, және мингвистикалық көзқарастарды қамтып, дін тілінің күнделікті қолданыстағы тілден өзгешеліктері оның діни тұжырымдарды толыққанды жеткізіп, сенушілер санасына ықпал ете алуына тікелей септігін тигізетіндігін көрсетуге бағытталады. Зерттеу жұмысының нәтижелері дискурсивті талдау жүргізудің ерекшеліктері мен жолдарын көрсетуімен және осы нәтижелерді қолдануға жол көрсете алуымен маңызды. Зерттеу жүргізу барысында жалпы және жеке ғылыми әдістердің көптүрлілігі пайдаланылды. Аін тілінің өзіне тән ерекшеліктері айқындалып, олардың мәні мен қолданысы жайлы тұжырымдар талданып, дін тілінің жалпы және барынша толыққанды бейнесі қалыптастыры^ды. Аін тілінің жалпы сипаттамасын, мүмкіндіктерін біку көптеген діни мәселелердің шешімін тауып, алдын алуға өз септігін тигізеді.

Түйін сөздер: тіл, дін тілі, таңба, рәміз, мингвистика, діни философия.

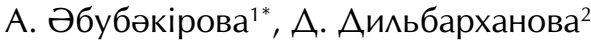

'Египетский университет исламской культуры Нур-Мубарак, Казахстан, г. Алматы 2Международный казахско-турецкий университет имени Ходжа Ахмеда Яссави, Казахстан, г. Шымкент *e-mail: a.abubakirova.work@gmail.com

\section{Аискурсивное изучение особенностей языка рекигии}

В настоящее время религия интегрирована практически во все сферы жизни человека, пережила период возрождения и развивается в новом направлении. Поэтому дискурсивное 
исследование религиозной проблематики, то есть анализ вопросов, связанных с религией в контексте современного дискурса, является важным и актуальным направлением исследований. Учитывая, что целью Аанного исследования является выявление и описание особенностей концепции языка согласно его природе и использованию в религиозном контексте, которая тесно связана с концепцией религии, основные направления исследования включают религиоведческие и кингвистические взгляды, а основной целью статьи является Аемонстрация того, что отличия языка религии от языка повсеАневного использования напрямую способствуют его способности влиять на сознание верующих, полноценно передавая религиозные утверждения. Результаты исследования актуальны, они показывают особенности и способы проведения Аискурсивного анализа и важны д^я Аальнейших исследований. Авторами статьи использова^ись различные общие и индивидуальные научные методы. Выявлены особенности языка религии, проанализированы и слеланы выводы об их значении и употреблении, сформирована общая и полная картина языка религии. Знание общих характеристик и возможностей языка религии помогает находить решение многих религиозных проблем и предотвращать их.

КАючевые слова: язык, язык религии, знак, символ, мингвистика, религиозная философия.

\section{Introduction}

It is well known that religion uses written or spoken language to convey information about itself to believers. In describing religious principles, preference is given to words that are deeper, more sacred, and have a more mystical color than the ones that the followers can understand and use in everyday life. It is not appropriate to consider the language of religion only as names given to ready-made religious symbols and concepts. We can think of religious rites, things, concepts, beliefs only on the basis of the names established by the language of religion. Thoughts cannot arise outside of language. The origin of thought, its reflection in the human mind, and its manifestation through the means of speech - all go through language symbols. The hypothesis offered by W. Humboldt about the hidden metaphysics of each language was developed by A. Potebnya in a new way almost a century later. In addition, in the twentieth century E. Sapir and B. Whorf proposed the "hypothesis of linguistic relevance". According to this hypothesis, language and thinking are directly related, and national forms of thinking are as different as their material shells - ethnic languages (Borodai, 2013: 18). Due to the diversity of the metaphysical content of ethnic languages, it is impossible to translate a text from one language to another, in that sense, which it was in original language. On this basis, we conclude that the terms of one religion cannot be given or explained in full by the terms of another religion. Language is reflected in any sphere of human life. Moreover, what can be described and represented by a symbol will take place in our minds and will be able to change us. In this way, language can make an individual subject to society. The life of a religious person is connected with symbolic, sign reality. The language of religion, on the other hand, is a means of exchanging high thoughts and lofty ideas. Since religion is an important foundation of human history and culture, the language of religion also becomes the basis of social life, human relations, and gives some transcendental meaning to life and falsehood. There are four main groups of terms that religious terms identify: a) absolute value (God); b) the values of the ultimate goals (the kingdom of God, the eternity of the soul, paradise); c) earthly means (religion, church, faith, cult) aimed at achieving these goals; d) the values of everyday life, which religion makes sacred. In a special, sacred language, believers convey the following: a) miraculous phenomena (the annual Easter miracle of the sacred fire in Jerusalem, the transformation of icons that make miracles, the miracle of glossolalia); b) thoughts about sacred things (the idea of absoluteness, thoughts about paradise); c) mystical experience (experience of numinous, state of meditation, realization of the truth from "above"); d) beliefs (in the Creator, the Savior, the innocence of the Church); e) cult practice (liturgy, the secret of the Eucharist, the Crusades) (Pivovarov, 2006: 231). As religious experience accumulates, it takes a linguistic form and is grouped in the holy books and their interpretations. Important, recognized sacred writings are at the pinnacle of literary art and are highly respected not only by the believers of that religion, but also by the general readership for their deep meaning and mastery. The followers of the religion pay special attention to the issues of complete preservation of the sacred texts of their religions, to correct transmission to the next generation, to correct distribution and interpretation among the believers, and to correct translation.

\section{Justification of the choice of articles and goals and objectives}

The language of religion, like any other field, has its own set of rules and regulations. In many 
cases, it does not obey the grammatical, syntactic, and logical rules of the language we use in our daily lives. Therefore, the language of religion becomes more exact and clearer in the context in which it is used. We can determine whether a language is a language of religion through special linguistic features. The use of that language directly affects the structure and delivery of the messages we want to convey. This research aims to analyze the language of religion, to determine its features in order to solve the problem of meaning or significance in the use of language.

Due to the fact that the use of language and the meaning imposed on language units require special attention, the study analyzed these aspects of the language of religion and described different views. The study analyzes the specific linguistic features and nature of the language of religion. Taking to consideration the importance and complexity of this discourse, it is clear that the study will be useful for researchers in this area.

\section{Scientific research methodology}

The methodology used in this study was selected in accordance with the research areas and questions outlined in the introduction. Sources include sacred texts of world religions, works of domestic and foreign scholars. The collected data were analyzed linguistically and religiously, and the features of the language of religion were identified by the method of content analysis. Functions inherent in the language of religion, such as artistic description, encouragement, persuasion, information, and emotional units, ungrammatical structures, archaisms, neologisms, etc., were studied by analysis and synthesis, and the characteristics of the language of religion were systematized.

\footnotetext{
Main part

Discourse on the definition of the language of religion

If we give a general definition of "language", we can consider language as a system of written or spoken symbols, and its functions as a tool for people to learn about the world, interact, create a society, live as a member, create and use culture. The language of religion is the symbolic, sign reality of religious thought, that is, the expression of oral and written religious texts and their use. Through the use of religious language, the believer is able to place to his inner world invisible and outside the world religious concepts and characteristics, in accordance with the ability and level of his language to describe. Religious language also has a profound
}

effect on a believer's behavior in the environment, his relationships with people, and his assessment of his achievements or mistakes in accordance with the requirements of religion. The language of religion is universal, it can be used in any sphere of human life, and is able to make and form new concepts and notions.

All language operations in human life are carried out using natural or artificial language. Although it is unknown who, when and how created the natural language, we know that it is constantly replenished. Natural language is a language of everyday use. It has many components, each with several meanings, not a specific meaning, and in many cases, the idea itself is determined only by the context. Many of the characteristics of natural language also apply to religious language. Because the transmission of religion is carried out primarily through the use of this natural language. The authors and dates of publication of artificial languages are known. For example, the alphabet of radiotelegraphy invented by F. Morse, the Esperanto language developed by L. Zamengoff. Artificial languages appear in large numbers for a specific purpose, to meet some of the needs of humankind (mathematical symbols, formulas, traffic signs, signs used in social networks, mood indicators, etc.). The symbols of these languages contain only one meaning and represent a specific message. The expansion of the language fund is based on content from natural language or other areas of culture.

A religious language is a combination of these two languages or a special structure that lives on the border of the aforementioned two. Paying attention to the fact that every religion is headed by a founder or a prophet, a religious language is a semi-natural, semi-artificial language, and its creator is known. The prophet conveys the truth to the people in new religious terms, not in simple words. It is usually the language of the prophet that later became the sacred language and was respected and spread by the believers. The main operation in the new religious language is to give new meaning to the concepts and notions in the natural language of that people. Once these new meanings are accepted, clarified, and become traditional concepts, they are translated into other languages as religion spreads. The new meanings of these simple words are far removed from their use in the natural language, and are enriched with key words from the natural language of the prophet, giving rise to a new, semiartificial language of religion. The reason we call it semi-artificial is that even people who do not know a particular religion can perceive information in this 
language and understand its meaning, even if they do not understand it deeply. Among the languages of the prophets, enriched with the religious content we describe, we can include the following: for Muslims - Arabic; for Christians - Greek and Latin; in Judaism - the ancient Hebrew and Aramaic languages; for followers of Hinduism - Vedas, Sanskrit. In this regard, it should be noted that the Orthodox Church fought and won the struggle for the establishment of the ancient Church Slavonic language as its own cult language. "The criticism of "trilingual apostasy" by the early Slavic enlighteners, Cyril and Methodius, affirmed the right of the Slavic language to "apostolize" and elevated it to the level of divinity" (Bezlepkin, 2002: 7). This language continued its literary development in the Church Slavonic language.

The language of religion is more ambiguous, vague, and broad than other languages that we recognize as "artificial". Because the language of religion contains many analogies, allegories and metaphors. The artificial languages of theology and religious philosophy are manifestations of abstractions arising from the languages of religion. They move away from the natural language and acquire the characteristics of the language of science. The average believer does not fully understand these languages, and in order to understand them, it is necessary to have a basic knowledge in these areas. Man communicates with the absolute through the language of religion, and the interpretation, description, definition of aspects, causes and consequences of this relationship is carried out with the help of the languages of religious philosophy and theology.

The symbolic and sign nature of the language of religion

There are various definitions of the word "language". English philologist H. Sweet describes language as "the expression of thoughts through the sounds of speech combined into words", American linguists B. Bloch and L. Trager explained, "Language is a system of random, freely derived vocal symbols through which a social group provides the communication of its members". According to the first definition, the appearance of the symbols of the language of religion is not so important, but the religious meanings they represent. According to the second definition, we must pay attention to the nature, appearance, linguistic structure of the symbols of the language of religion. Both of these principles must be taken into account in order to fully understand the language of religion. In order to understand and analyze the material aspects of the language of religion, we need to pay attention to the following issues. As soon as a person is born, they can express and satisfy his needs through various sounds. As they grow older, these sounds become a set of meanings for a particular language and begin to form words and sentences. They help people to communicate and exchange ideas. However, two people who speak the same language can never speak identically, that is, they cannot use the same sounds and produce the same sounds. However, we cannot call the peculiarities of the language, which appeared according to the peculiarities of each person, a kind of a new language. The main thing is that the interlocutors should be able to understand each other without any additional training or preparation. In the same way, religious sects or directions that are based on the same religion but have different interpretations can build mutual understanding and tolerance whether they use the same language. And if members of the same religion describe and spread their teachings in different languages, different meanings and misunderstandings may arise. For this reason, the main prayers in Islam, the call to religion, are performed in any part of the world in Arabic, the language of the common prophet for Muslims. Disputes and issues can be resolved on the basis of religious books and literature written, recognized and accepted in Arabic. Translations of the Holy Qur'an are not equated with the Arabic Qur'an, and the translation is not considered as the Qur'an. From this, we can see that Islam and Muslim scholars pay special attention to language features and opportunities, difficulties and problems, and prevent possible misunderstandings.

Although a foreign language is often unpleasant and unacceptable in everyday life, the language of liturgy, which is incomprehensible to the general public, can evoke feelings of respect, fear, and hope in the listener. For example, the Church Slavonic language, which is used in worship in the Orthodox Church, is specially studied by church workers and fathers. Ordinary people who come to worship, even if they do not understand the language, show a special respect for the process with its melody. Another example of such an incomprehensible but respectful religious language is the phenomenon of glossolalia (from the Greek glossa - an incomprehensible word, lalein - speech). By this term, we mean the believer speaking with God in the unfamiliar language of the angels, miraculously given to the believer by the Holy Spirit. As an example, we can illustrate the phenomenon of speaking in a language unlike any other language in the world, which takes place 
at a meeting of members of the Church of the Pentecostals.

Religious thinking uses all forms of emotional, symbolic, sign thinking and thought expression, and includes the basic types of verbal and non-verbal thinking. For a conscious person, the world or any part of it can have two different interpretations: emotionally defined signs; the meanings that these signs have that cannot be identified by the sense organs. Heaven itself, the celestial bodies are a special book written by God for believers, a universal system, the meaning and significance of which can be determined only through the sacred scriptures. Ilarion Alfeev, an Orthodox hegumen, elaborated on this concept: "The universe created by God is a revealing book for those who can read the greatness of the Creator. Unbelievers cannot look at the material world and see the image of the Intangible Supreme Beauty: for them there is nothing amazing in the world, everything is simple and trivial. The Book of Miracles of God is read only through believer's eyes. A well-known philosopher came to Anthony, a fourth-century Egyptian hermit, and asked, "Ava, how do you live here without the comfort that comes from reading a book?" Anthony pointed to the sky, the desert, the mountains, and replied, "Philosopher, my book is the nature of created things, and I can read God's works from them whenever I want" (Ilarion (Alfeev), 2000: 71).

Although all kinds of symbols are used in the language of religion, the main role here is given to the symbolic language. Hegel wrote in his Lectures on Aesthetics: "In general, a symbol represents an external being that exists or is given to be felt, but it is not taken as a thing living for itself, but must be understood in a broad and general sense" (Hegel, 1969: 14). A symbol is a sign that reveals the nonemotional content of an object, connecting the lower and upper layers of being. A symbol does not only represent a specific object, but also all the feelings, concepts, and emotions that arise in relation to that object. The religious symbol evokes feelings in the believer by naming a certain sacred object. For Christians, for example, the cross symbolizes the complete mystical history of God the Savior, awakening in them the belief in salvation and the hope of eternal life. Taking into account this symbolic nature of the language of religion, we can clarify the paradoxes that arise in the understanding and interpretation of religious ideas. On the one hand, the religious conceptions of eternal, divine existence contain deep meanings and infinite wisdom. On the other hand, religious thought is ambiguous in nature, so it is not clear, but hidden. For this reason, a special state of understanding and cognition is formed in the language of religion. For example, scientific knowledge in the natural sciences is based on the understanding of some objective, real meaning from their texts. Scientists in these fields believe that the languages they use have a knowledge of objective reality. They try to express their views on this knowledge in a neutral, uninterested way, with no regard for their own implication. They believe that the object they are studying is recognizable, that there is an objective reality.

If we refer to metaphysical religious ideas, not empirical ones, the language of religion is associated with an axiological form of understanding, not an epistemological one. Knowledge of God is not a real, neutral, objective knowledge of the nature of God. It is impossible to understand fully the nature of God, nor is it required of believers. Because God is inaccessible and is not considered an object of knowledge and study. Religious understanding is usually subjective. The individual believer's desire for the sacred world, objects, phenomena and curiosity determine the dynamics of actions in relation to them. The concept of religion is closer to the reality of life than to the epistemological reality. Therefore, in the religious understanding, objective knowledge depends on the existential individual meaning. Knowledge of God is not a knowledge of the true nature of God, but a subjectively interpreted manifestation of the finite attributes He has bestowed upon His creatures. Hence, the religious truth is that our empirical life meets the requirements of a pious way of life. Compared to the language of the natural sciences, the language of religion describes existential meanings rather than objective meanings due to its metaphysical components. It sets out the conditions for striving for the Absolut, showing that it is not available to man. Both science and religion are based on the simple natural language of everyday life. They take from it terms that are suitable for describing their subject and change their meaning. Nevertheless, while scholars have made language a means of communication for a small group, a narrow circle, through frequent and large-scale changes, clergy emphasize the need for the language of religion to be understood by a wide audience. Religious language is used to express thoughts about the absolute and the emotional world given to us. Attitudes towards the object of religious belief can be expressed in both ordinary language and the language of science. It is no secret that religious thought and knowledge have a great influence and contribution to the formation of scientific knowledge. Theological evidence and 
concepts for God's existence is based on scientific methods. Thus, the languages of religious and scientific directions are constantly evolving.

The language of religion is used for believers to express ideas in two different directions. The first is the ideas of transcendental events (God created man). Opinions in this direction are not subject to scientific evaluation, that is, we can not prove it true or false by any scientific method. Only a logical conclusion based on faith or only true faith is the basis for acceptance. The second is factual reasoning (made man the most beautiful creature). Conclusions in this area can be verified by scientific methods, proven to be true. Religious language is freely used in conversations about God and the qualities of the created world. There may be subjective contradictions between these two directions of religious thought. This is because much of the text of the sacred books is based on metaphors and does not provide clear information. And its interpretation and perception will vary depending on the level of basic and scientific knowledge of a researcher.

The same contradictions and differences exist between empirical and theoretical scientific conclusions. This is because the theoretical information about a particular scientific object may not fully correspond to the empirically collected data, depending on the reality of the environment. When we talk about the contradiction between science and religion, we often do not correctly identify the categories we have described above, and as a result draw contradictory conclusions. For example, when we reconcile religious and empirical scientific concepts about the transcendent world, we inevitably encounter great opposition and conflict. And if we reconcile the religious factual conclusions about this world with these empirical scientific conclusions, we can get harmony or an understanding that will emerge over time.

What is the meaning of the symbol, how do we understand the meaning of the religious symbol, where do these meanings come from? There are several answers to such questions in the philosophy of language. Let us look at the directions in which those answers are combined.

1. Essentialism (Latin essentia - being) arises from the thesis that the meaning of symbols arises from the transcendent or immanent nature of things around us. According to Plato, the names of individual things are similar to their otherworldly idea; the material object is a shadow of the idea, behind the symbol of the object is hidden the ideabeing that creates it. Aristotle, on the other hand, replaced Plato's idea-beings into the things on earth and described them as immanent forms of things: the name of a thing is its intangible form (essence). According to Plato and Aristotle, the sound of the oldest words may be reminiscent of the phenomenon they call, but due to the proliferation of new words and the fact that the first terms became just radical, the similarity between the sound of words and the phenomena they denote began to weaken and became inconspicuous. From that time on, the relationship between symbol and meaning began to be governed by conventions, that is, by social agreement and tradition. Late Neoplatonism and medieval realism interpreted existence as a book of divine meanings and constantly highlighted the objective content of the text and the object itself. For them, the original word was in God, and the symbols of the true language represent all divine beings. It follows that the meanings of key words should be taken from the correct interpretations of the Bible. Thomas Aquinas, on the other hand, assumed that the meanings of general terms had three different natures: a) they represented transcendental and eternal ideas in the knowledge of God; b) divine ideas are reflected in things and become the inner form (essence) of those things; c) lives in the human mind subjectively in the form of general concepts. In conclusion, followers of realism and Platonism look for the meaning of names in the otherworldly divine ideas; Aristotle's followers claim that the meaning of the symbol originated in this world, that it is a hidden property or the ancestral nature of several similar things. Essentialism also faces a number of logical challenges. However, such logical contradictions in essentialism should not be seen as a manifestation of its intellectual underdevelopment. For example, the logical sequence of realism in Christianity ultimately combines reality with the notion of God as a whole, rather than the Trinity of images in God. Philosophers and antinomists welcome the existence of such contradictions within a doctrine and consider it as a sign of the viability of the doctrine.

2. Nominalism (Latin nomen - name, noun) is a direction that proves that in objective reality there is only individuality, nothing is general, common. The word universal was coined to describe a particular individual. Some nominalists argue that commonality can exist not only in the external world, but also in the mind of the subject in the process of cognition. For example, Christian nominalists recognize not only a homogeneous God, but also three separate figures. At the same time, they do not recognize the consistency between the truths determined by religion and science. Subsequent nominalists, 
especially historians and source scholars, do not recognize religious studies as a science that meets the requirements of nominalism. The main disadvantage is the interpretation of all religious phenomena in accordance with the principles of the general objective laws of development of society. It also denies that it is wrong to give general, common characteristics to religion and the structural elements of religion, and that the aspirations for truth of religions are the same. Representatives of religious fanaticism can also be considered followers of nominalism, because they do not want to see and recognize any similarity between their only true religion and other beliefs.

3. Conceptualism (Latin conceptus - concept), unlike the above directions, seeks the meaning of symbols not from objective reality, but from subjective reality, such as human thought, consciousness. As an example, we can consider the work of Peter Abelard, who developed the theology of critical linguistic analysis. He argues that the clergy teach issues that they do not understand, and that many of the findings in the Scriptures need to be reasoned and tested. Hence, his famous statement, "I understand to believe" appears. Followers of conceptualism recognize that different concepts may be based on the same word, and that the possibilities and degrees of alternative interpretations of the Scriptures are equal. Here arises the basis of the principle of tolerance: God guides all humankind to the truth in different ways, so there is a spark of truth in every teaching. Let us disuss the positions and conclusions of Islamic scholars about this direction. The Holy Quran states: "We have not sent any prophet except to speak in the language of his people, so that he may explain it to his people" (Akimhanov, Anarbaev, 2020: 14: 4). The prophets spoke the language of the congregation to which they were sent, and they preached in that language. Therefore, they follow the linguistic laws of the language and convey their thoughts and teachings taking into account those features. Traditional trends in Islam accept and understand the use of ambiguous words, metaphors, allegories, metonyms or figurative language in the transmission of religious teachings. A clear example is orthodox Islam, that is, the fundamental discrepancies between the four basic and fully recognized regulative schools of Sunni Islam on some issues. These discrepancies or contradictions arise as a result of the ambiguity of words in religious texts and the choice of meanings by the founders of each school so that they do not go beyond the requirements of religion. Al-Asmandi says in "Bazl al-Nazar" on this subject: "Linguistics precedes the Shariah", while Ibn Taymiyyah in his book "Daru Taarud an-Naql wal-Gaql" says: Because no one knows the true meaning of these words except Allah, it leads to the destruction of the mind and religion" (Sabdin, 2020: 67-68).

4. Verificationism (Latin veritas - truth, verification - the definition of reality) appeared in the twentieth century as a view of the followers of logical positivism, and showed the principle that the meaning of the concept is a method of empirically examining it individually. For example, if the phrase "there were 12 apostles with Jesus at supper" is considered meaningful, believable, because it can be tested by someone in the past and verified, the phrase "Jesus Christ is the Son of God" is meaningless, because there is no factual resource to verify any characteristic of God. However, since the principle of verification itself cannot be empirically and logically verified, we can include it in the list of meaningless concepts using its own method. At the same time, any conclusion about God, about phenomena that cannot be known through the senses, is aimed at understanding the essence, not at understanding it directly. There is even a view that divine beings and phenomena can only be instructed and directed, but cannot be described. The language of religion can perform both cognitive and noncognitive functions. These include instructional, evaluative, symbolic, emotional, and performative services.

5. Syntaxism (Greek syntaxis - sequence; meaning of phrases and sentences) refuses to look for the meaning of symbols outside the text. To understand the text, it is enough to pay attention to its internal harmony. For example, the verses of the Quran, which are read eloquently in Arabic and captivate even the most incomprehensible person with their harmony, lose their beauty and elegance when translated into another language and become a simple text. Followers of postmodernism and poststructuralism describe existence as a continuous, endless text. There is nothing higher than language reality, and there is no hidden divine reality. This is where nihilistic views begin. Theologian Don Cupitt says that religious terms do not define, mark or copy religious objects, and there is only a world of visible phenomena, which must be analyzed philosophically as a world of symbols. He concludes that the gods are nothing more than what we say about them (Thompson, 2001: 122-124). According to $M$. Foucault, the modern mentality is characterized by a complete lack of belief in meaning. The general logosphere consists of a chaos of meanings, and is considered by some postmodernists as an "impossible 
glossary", "heretical discourse". However, the most striking critique of this postmodernist syntaxism and its nihilistic attack on the structure of the classical tradition is said to itself. Representatives of syntaxism describe it as a "stream of meaningless knowledge" and point out that the conclusions and theories proposed in this direction should be viewed with skepticism, and must go under rigorous analysis and scrutiny.

6. Operationalism (Latin operatio - action) seeks the meaning of the symbol not from the object and the subject, but between them, from their relationship, from practical and theoretical actions of the subject. In the language of religion, the meaning of any symbol in general includes objective, operational, subjective, evaluative components in certain relationships. Therefore, operationalism can be considered as a dialectical synthesis of such areas as essentialism, nominalism, conceptualism, syntaxism. Language is the mediator between experience and knowledge. Here we understand the experience as a materially oriented action of the subject, which can change the object. From experience language takes methods of changing things. Each method is a model of an individual object in the process of action, and it implicitly conveys information about any part of this object in its structure. On the part of cognition, language can explicitly convey objective information specified in these symbols and relate it to objects. Vocabulary is a tool for the implementation of the thinking process. We can show the structure of the active language by a formula that includes three parts: "object-language - speech action - subject-language" (Pivovarov, 1987: 4). The language of religion, especially its use in the memorization of sacred texts, is characterized by the formula: "sacred text - confessional speech - a personal interpretation of the believer". Now let us explain these formulas. The concept of objectlanguage refers to a set of symbols that replace objective connections and relationships in practical action. They can also identify some aspects of material reality that are not relevant to the practice. For example, the object-language of religion is libraries, where sacred records and documents of confessional traditions are kept, traditions and rituals. The function of object-language is to replace the connections and relationships that are independent of the cognition of the person using the language in a particular situation. In the sequence of the signs of this language, the objective and personal interrelation of things is preserved. The use of object-language allows you to consider different options for action. Object-language information is a set of interconnected information, and subjectlanguage can extract this information only by subjecting the object-language to various changes. The object-language of religion is a manifestation of the cult practice and the linguistic actions of its believers are addressed to it. The subject-language of religion is the reality of the thoughts of the believer, through which the individual religious thought is reflected. The subject-language of religion is a personal and subjective translation of the objectlanguage of religion performed by believers in speech. It follows that there may be inconsistencies and contradictions between the object-language of religion and the subject-languages, that seek to interpret and convey it, within the subject-languages themselves. The diversity of the subject-language depends on several factors: the personal experience of the believer, his level of mastery of sacred symbolic reality, the peculiarities of their relation to cult practice, the validity and degree of religious knowledge, the peculiarities of the sources guided in learning and understanding religious terms. In the process of religious thinking, language operations are reflected as a transmitter of information from object-language to subject-language. Although the number of specific symbols used in the language of religion to convey religious ideas is small, the depth of the object-language and the use of different linguistic, literary rational methods reveal for the subject-language a variety of ways to formulate and convey their conclusions. Religious thoughts begin to be actively expressed in the believer through the subject-language after the interaction with the objectlanguage. Through cult speech, the believer becomes a subject of religious communication and creates an immanent dialogue with the absolute. Recognizing religious beings by their object-language names, the subject-language begins to perceive and describe them in accordance with their understanding. Some of these new and personal interpretations may lead to a new direction in religion.

Dividing the language of religion into two components in this way helps to find the answer to the question "Can we think of supernatural things around us, which does not exist in this world?" If we look at it syntactically, we can explain the emergence of the image of objects that do not exist in the world as a result of ritual linguistic processes carried out using ethnic object-language words. In the beginning, the words that denote the realities common to ordinary people have a special connection that cannot be described, and have become objects of faith through the metaphors of cult language. Thus, these symbols replenished the natural object-language fund and 
became the symbols of objects that do not exist in this world. After this the language of religion begins to develop on its own. For example, in Islam, the concept of paradise is conveyed to the human mind through the descriptions and concepts that exist on earth, but because it promises a multiplicity of miracles, so the followers of the religion do not fall into a state of cognitive dissonance and believe unconditionally. The believer consciously accepts all the characteristics and expects more, so there is no problem in terms of trust.

Now let us explain the process of speaking, which connects the object-language and the subjectlanguage. We take the language symbol "Speech" here as the replacement for the words "outspeak", "speak up", "declare", "express". This is because any of these words is not perceived in a narrow sense, which is what we need when the reader sees it, that is, as the verb that indicates that the thought in the human mind, in our case religious thought, takes on a material form and reaches a particular side, but in a broader sense. Therefore, when reading this "speech", we should understand it as a way to convey the concepts of object-language to the subject-language. In linguistics, there are several meanings of the concept of speech: speech as a result of linguistic activity and as linguistic activity itself. Religious speech becomes a linguistic model of the believer's thought, thereby reflecting the form, properties, characteristics, individual features and characteristics participial to a group of the religious object, concept. Therefore, religious speech has an operational and material nature, both as a linguistic action and as a result of linguistic action. In this context, the language of religion can be divided into belief constants and religious performatives. Constants are cognitive in nature and convey a clear and unchanging truth: "There is a God", "Do not sin", "Punishment will be severe". Non-cognitive performatives, on the other hand, do not distinguish between truth and falsehood, do not inventory what exists or do not exist, and only mark actions such as doing something, making a statement, showing will and emotion: "Let's pray", "God bless you", "God forgives", "Let it be accepted", etc. However, due to the peculiarities of the language of religion, there is neither a pure constant nor a pure performative. While saying, "It is not permissible to sin", the believer acknowledges in his mind that there are times when he has to commit sinful acts. While saying, "God forgive", the believer believes that God is merciful and he might be forgiven. A religious symbol has a material body, a meaning, that is, a mental image of meaning, and a spirit that comes from outside to the body of the symbol, reflecting the transcendent meaning of the symbol.

In the context of religious philosophy and theology, the human language is described as a divine being. Followers of Hinduism say that the god Indra created speech; Plato's writings say that the gods invented the first and most correct words, in Sumerian and Babylonian culture - Nabu, in ancient Egypt - Toth, in ancient Greece - Hermes, in Scandinavian mythology - Odin created writing and runic alphabet. In any case, since the creation of the world, the word and the thing it calls are closely related. To know the name of a thing is to have it. Since time immemorial, people have not stopped looking for hidden meaning and energy in the name of a thing. This trend was especially widespread in the Middle Ages, which was called the "culture of text", "culture of interpretation of scriptures". Later, suggestions were made to create a language that would be common and understandable to all humankind. For example, in 1887, the Polish L. Zamenhof, who supported the ideas of Bahá'u'lláh and followed him, proposed an auxiliary language "Esperanto" based on the Latin alphabet.

\section{Results and discussions}

After the Second World War, the revolution, which covered all areas of science and culture, also affected linguistics. Linguists began to pay attention to how language is used in real communication. And "context" became the most important and frequently used word (Hutchinson, Waters, 1987: 7). It was concluded that the use of language can take different forms depending on and accordingly to the context. The language of religion began to be excluded from everyday communication. Because only religious minorities could fully understand and apply it. Since religion itself touches on serious, spiritual, and sometimes tragic, frightening topics, the language of religion offers a set of words used in similar discourses. Also the texts of the Scriptures cannot be adapted to everyday life. The language of religion is full of metaphors and ambiguous words. Words and phrases that have no meaning at all or have a different meaning in simple usage can be considered as a meaningful structure in a religious context. Religious language also has meaning in the context. The meaning of religious words is best explained in the context in which they are used, rather than in the abstract (Etim, 2006: 27). For many peoples, the language of religion is characterized by loan words, the widespread use of archaisms. The reason for this is that the language of religion does not lose contact with the language from which the religion originated 
and the sacred writings were delivered. However, religious categories can take advantage of modern language and add it to their vocabulary (Islamic banking, Islamic economics, Christian management, etc.). The language of religion has structures aimed at praise and persuasion. We can see it in the sacred writings of any religion. Followers of the religion use words, phrases, sentences, etc. lexical units in a way that is different from their use in everyday life and that is understandable to this limited group. The language of religion has a very large vocabulary and it is different from other forms of language use. Words help to create a unique system of lexicon in the language through the use of archaisms (Ekpo, 1991: 2). The language of religion is a poetic language that widely uses such tools as antithesis, paradox, inversion, metaphor, allegory. The main evidence for this is the Scriptures. The sacred texts of any religion are beautifully organized, aimed at influencing the human mind and heart. And the information provided must be explained without deviating from the context.

Here are some examples of commonly used linguistic tools in the language of religion from Christian sacred texts. The phrase "here is the Lamb of God" (John 1:29 KJV Holy Bible) is an example of a metaphor for Jesus, referring to the word lamb. The phrase "Behold, I come as a thief" (Revelation 16:15 KJV Holy Bible) illustrates the use of comparison. Because it is about Jesus again, and he is coming as a thief whom no one is waiting for. The passage "Therefore I have spoken to them" (Matthew 13:13 KJV Holy Bible) shows that the correct sequence of words in a sentence of religious language is replaced. And the archaisms in the scriptures can be understood only by followers and researchers, and can be seen as a collection of meaningless letters for irrelevant people. What we understand from these examples is that the figurative concepts used in the language of religion must be interpreted in the context. And looking at them separately does not allow to achieve the real meaning. We also notice that the language of religion is adaptable to listeners and students, followers and believers. Special language tools and words are used to make the information conveyed to the recipient effective and complete. For example, hyperbole, exaggeration are used in the description of God, and they are aimed at the filling the listener's mind is with a powerful emotional image of God. In addition, the specific languages of some religious communities are composed of words that are completely incomprehensible, not found in any other language in everyday life, and are used in religious activities and ceremonies (for example, the worship languages of some groups of Pentecostals, glossolalia, etc.).

The language of religion is also characterized by a wealth of loan words. For Christians, the loan words are from Latin, Greek, and Hebrew, while for Muslims, the loan words are from Arabic. These words may require a full translation and interpretation for an outsider, even if they are in use and retain their phonology and orthoepy in the same language, without the need for explanation for those involved in religion. Archaisms, which are widely used in the language of religion, are passed down from generation to generation without changing, in order to show the stage of formation and features and degree of language, as well as for clearly defining a religious concept. However, neologisms have been added to the list of modern religious terminology, which shows that religion is not shying away from humanity in the tide of time, on the contrary it develops and lives, closely related. If the linguistic features of the language of religion analyzed on the basis of examples will be used rationally and in the right situation and context, the language of religion will be a useful tool in building relationships between people, in the main function of language.

\section{Conclusion}

The help of linguistic methodology in the study of the features of the language of religion can be determined only by knowing how religious studies in general is considered in the context of linguistic methodology. And this is possible only by revealing the relationship between language and religion, the main objects of research in these two disciplines. The data, descriptions and conclusions collected during the study revealed the peculiarities of the language of religion, and showed that for their formation several options for the relationship between religion and language can be concluded: as religion and language are related, cultural phenomena that develop under the same laws, we can conduct a research according to the same methodology. Religion and language can also be described as products of each other. Religion can be considered as a result of linguistic processes, and in the theological context language can be a product of religion. Religion and religious phenomena are considered as communicative, symbolic systems, religion appears as a cognitive system that transmits information about this and other worlds to the descendants of believers. After the linguistic revolution in philosophy, the analysis of the language of religion became the main paradigm for analytical philosophy, and 
the language of religion is considered as a set of religious concepts, religion itself as a system of these concepts. Religion and language are considered as a form of human life. Linguistics analyzes and reveals the meaning of religious texts and scriptures, and interacts with believers, researchers, and seekers to convey meaning.

Of course, these versions do not cover all aspects of the deep and unbroken connection between religion and language, linguistics and religious studies. In our turn, we have described and identified the main object of study arising from this connection - the features of the language of religion, looking at each aspect of the established relationship.

We hope that the results of the study will become a useful resource for those who want to study the relationship between religion and language.

\section{References}

Акимханов А.Б., Анарбаев Н.С. (2010) Құран Кәрім (қазақша түсіндірмелі аударма). «Ибраһим» сүресі, 4 аят

Безлепкин Н.И. (2002) Философия языка в России. К истории русской лингвофилософии. - СПб.: Искусство. - 7.

Бородай С.Ю. (2013) Современное понимание проблемы лингвистической относительности: работы по пространственной концептуализации // Вопросы языкознания: журнал, № 4. -18 .

Гегел Г.В.Ф. (1969) Эстетика в 4-х т. - М.: Искусство. Том 2. - 14.

Etim, F. (2006) Issues in Philosophy of Religion. - Uyo: Afahaide \& Bros Press. - 27.

Ekpo, I. (ed). (1991) An Introduction to the Study of Religion. - Lagos: Time Publications. -2.

Hutchinson, T., Waters, A. (1987) English for Specific Purpose. Cambridge: C.U.P., p. 7

Иларион игумен (Алфеев) (2000) Таинство веры. Введение в православное догматическое богословие. - Клин. -71 .

KJV Holy Bible, King James Version (2017) by Christian Art Publishers.

Пивоваров Д. В. (2006) Особенности языка религии // Научные труды профессоров Уральского института экономики, управления и права. - Екатеринбург. № 3. - 229-263.

Пивоваров Д.В. (1987) Операционный аспект научного знания. - Иркутск: Гл. 4, 176

Сабдин А.К. (2020) Теологические нарративы дерадикализации: методическое пособие. - Алматы: Бскуаред. - 67-68

Томпсон М. (2001) Философия религии: пер. с англ. - М.: ФАИР-ПРЕСС. - 122-124

\section{References}

Akimhanov A.B., Anarbaev N.S. (2020) Quran karim (qazaqsha tusindirmeli audarma). «Ibrahim» suresi, 4-ajat. [Quran Karim (kazakh explanational translation). Surah "Ibrahim", Verse 4]. - 667. (in Kazakh)

Bezlepkin N.I. (2002) Filosofija jazyka v Rossii. K istorii russkoj lingvofilosofii. [Philosophy of Language in Russia. Towards the history of Russian linguistic philosophy]. - Saint-Petersburg: Iskusstvo. - 7. (in Russian)

Borodaj S.Ju. (2013) Sovremennoe ponimanie problemy lingvisticheskoj otnositel'nosti: raboty po prostranstvennoj konceptualizacii [Contemporary understanding of the problem of linguistic relativity: the works on space conceptualization]. Voprosy jazykoznanija: zhurnal, № 4. - 18. (in Russian)

Etim, F. (2006) Issues in Philosophy of Religion. - Uyo: Afahaide \& Bros Press. - 27.

Ekpo, I. (ed). (1991) An Introduction to the Study of Religion. - Lagos: Time Publications. -2.

Hegel G.V.F. (1969) Jestetika v 4-h t. [Esthetics in 4 vol.]. - Moscow: Iskusstvo, vol. 2. - 14. (in Russian)

Hutchinson, T., Waters, A. (1987) English for Specific Purpose. Cambridge: C.U.P., p. 7

Ilarion igumen (Alfeev) (2000) Tainstvo very. Vvedenie v pravoslavnoe dogmaticheskoe bogoslovie. [Sacrament of belief. Introduction to the dogmatic theology of the Eastern Church]. - Klin. - 71. (in Russian)

KJV Holy Bible, King James Version (2017) by Christian Art Publishers.

Pivovarov D. V. (2006) Osobennosti jazyka religii. [The peculiarities of the language of religion]. Nauchnye trudy professorov Ural’skogo instituta jekonomiki, upravlenija i prava. Ekaterinburg, № 3, pp. 229-263. (in Russian)

Pivovarov D.V. (1987) Operacionnyj aspekt nauchnogo znanija. [Operational aspect of the scientific knowledge]. - Irkutsk: Gl. 4. - 176. (in Russian)

Sabdin A.K. (2020) Teologicheskie narrativy deradikalizacii: metodicheskoe posobie. [Theological narratives of de-radicalization]. - Almaty: «Bsquared». - 67-68 (in Russian)

Thompson M. (2001) Filosofija religii / per. s angl. [Philosophy of religion]. - Moscow: FAIR-PRESS, pp. 122-124 (in Russian) 